\title{
Influences of probiotic bacteria on organic acid production by pig caecal bacteria in vitro
}

\author{
Takashi Sakata*, Taichi Kojima, Masatoshi Fujieda, Masanori Takahashi and Takashi Michibata \\ Department of Basic Sciences, Ishinomaki Senshu University, 986-8580 Ishinomaki, Japan
}

\begin{abstract}
The mechanism of action of probiotics is largely unknown. A potential mechanism should be to increase the production of short-chain fatty acids (SCFA), known modulators of gut functions, by the bacterial ecosystem in the large intestine. The present paper reviews our recent studies in which the capacity of probiotic bacteria to increase the production of SCFA by pig caecal bacteria was investigated using batch-culture and continuous-culture techniques. All four commercial probiotic preparations and three strains of probiotic bacteria dose-dependently accelerated the net production of SCFA, succinic acid and lactic acid without changing the acid profile, and slowed the net production of $\mathrm{NH}_{4}$. Effects on organic acid production did not vary among different probiotic species. Neither probiotic preparations nor probiotic bacteria affected the organic acid production from glucose, gastric mucin, starch or lactose, or organic acids produced:added saccharide. Glucose abolished these effects of probiotic preparations. However, the capacity of probiotics to increase SCFA production was not modified by gastric mucin, starch or lactose. These results indicate that probiotic bacteria increase SCFA production by accelerating the breakdown of carbohydrates that are resistant to indigenous bacteria, and suggest that the concept of prebiotics in terms of SCFA production as a measure of probiotic function is arguable.
\end{abstract}

Intestinal bacteria: Probiotics: Fatty acid production: Carbohydrate breakdown

Oral administration of living micro-organisms (probiotics) has been used to treat and prevent diarrhoea in human patients and farm animals, but no definitive mechanism of action has been established (Fuller, 1991; Okamoto et al. 1996; Siigur et al. 1996; Ito et al. 1997; Gibson \& Williams, 1999).

Short-chain fatty acids (SCFA) such as acetic, propionic and $n$-butyric acids are the main products of microbial breakdown of carbohydrates in the large intestine (Macfarlane \& Gibson, 1995) and constitute the major anions in the lumen of the large intestine (von Engelhardt et al. 1998).

SCFA provide energy to colonocytes (Roediger, 1995) and stimulate $\mathrm{Na}$ and water absorption from the large intestine in vivo, even under diarrhoeic conditions (von Engelhardt et al. 1998). Furthermore, propionic and $n$-butyric acids suppress colonic propulsive motility in vivo (Cherbut, 2003). Thus, it can be hypothesized that probiotics modify the metabolism in the microbial ecosystem of the large intestine to increase SCFA production and thereby increase $\mathrm{Na}$ and water absorption, and decrease colonic motility.
However, information relating specifically to the effect of probiotic bacteria on SCFA production by the caeco-colonic bacterial ecosystem is surprisingly scarce.

Accordingly, the present paper reviews our recent studies in which the effects of probiotic bacteria on the net production rate of SCFA, other organic acids and $\mathrm{NH}_{4}$ by the caecal bacterial ecosystem were investigated.

\section{Methodology \\ Estimation of organic acid production}

Earlier studies claiming a relationship between the probiotic bacteria and SCFA production often used SCFA concentration in the lumen or faeces (Bengmark \& Jeppsson, 1995; Siigur et al. 1996). However, lumen or faecal concentration is not a suitable predictor of production rate (Inagaki \& Sakata, 2001), due to the efficient absorption of SCFA from the colon ( $<5 \%$ is unabsorbed; von Engelhardt, 1995).

Theoretically, isotope dilution should be the 'gold standard' for estimating the production rate of SCFA (Pouteau et al. 2003). However, this method is expensive 
and, therefore, may not be the method of choice for the present purpose, which requires a factorial design involving a number of experimental groups. Further, the isotopedilution method requires different isotope labelling in order to monitor the production or absorption of different acids. Thus, an in vitro fermentation technique was adopted as an acceptable alternative. The batch-culture technique without $\mathrm{pH}$-stat was used for dose-response studies, in which different prebiotics were compared and the interaction between probiotics and additional bacteria was investigated. The one-step continuous culture technique without $\mathrm{pH}$-stat was also used for a time-course study (M Takahashi and $\mathrm{T}$ Sakata, unpublished results).

Changes in bacterial species in the culture were not considered because little is known about how and which kind of changes in bacterial composition in this ecosystem might affect host body function directly. On the other hand, the effects of various bacterial metabolites on host body functions have been well studied. Immunological stimulation might be a potential direct effect of gut bacteria. However, this activity requires direct contact of bacteria with the host mucosal surface, which may not be so easy for bulk-phase bacteria due to the mucus layer and biofilm at the mucosal surface and to the high viscosity of lumen contents.

Diluted pig caecal contents were used as the inoculum for our studies (Sakata et al. 1999). Pigs are an omnivorous colonic fermenter, as is man, and they have a body mass more similar to man than experimental rodents, and therefore may serve as an animal model for man. The relatively large caecum of the pig makes it possible to collect sufficient amounts of caecal contents to conduct a series of batch-culture or continuous-culture studies using the same source of caecal contents. Further, it is also the advantage that it is not necessary to kill animals for the purpose of the experiment.

\section{Inoculum}

Caecal contents were collected from five pigs of approximately $110 \mathrm{~kg}$ body mass at a local slaughterhouse (Senpoku Meat Inspection Centre, Yoneyamamachi, Miyagi, Japan) after the usual veterinary inspection. Pigs were fed commercial diets for growing pigs and fasted overnight before slaughtering. The caecal contents of five pigs were pooled and immediately mixed with an equal volume of bicarbonate buffer adjusted to $\mathrm{pH} 7.0\left(\mathrm{~g} / \mathrm{l} ; \mathrm{NaHCO}_{3}\right.$ 9.240, $\mathrm{Na}_{2} \mathrm{HPO}_{4} .12 \mathrm{H}_{2} \mathrm{O} 7 \cdot 120, \mathrm{NaCl} 0 \cdot 470, \mathrm{KCl} 0 \cdot 450$, $\mathrm{CaCl}_{2} .2 \mathrm{H}_{2} \mathrm{O} 0.450, \mathrm{MgCl}_{2} .6 \mathrm{H}_{2} \mathrm{O}$ 0.087). The mixture was filtered through four layers of surgical gauze, and the filtrate was kept at $4^{\circ} \mathrm{C}$ until used as the inoculum. Thus, the inoculum consisted of twice-diluted pig caecal contents.

This inoculum was thicker than the ten times-diluted faecal slurry widely used for the European batch-culture technique (Barry et al. 1995). The higher bacterial density in the present method should reduce the need for bacteria to proliferate to reach the normal density in the culture and thereby to use energy and $\mathrm{C}$ for their cell-body synthesis. In other words, the use of a thicker inoculum may reduce the underestimation of organic acid production and overestimation of bacterial cell-body (i.e. protein) synthesis. It should also be mentioned that our inoculum contained various substances such as bile acids and mucin usually included in normal caecal contents, but not substances that may be present in the large food particles. This inoculum was considered to be a better reflection of the large bowel environment than washed caecal bacteria or ten times-diluted faecal slurry.

\section{Batch-culture technique}

Batch culture was carried out without $\mathrm{pH}$-stat and without stirring using 1 or $5 \mathrm{ml}$ (Kiriyama et al. 1992). The use of an anaerobic buffer and the injection of $\mathrm{CO}_{2}$ into the culture vessel were the only anaerobic precautions taken; our earlier study (Kiriyama et al. 1992) demonstrated that this technique was sufficient to maintain anaerobic conditions, at least in the bulk phase of the culture.

\section{Continuous-culture technique}

Batch cultures have inevitable drawbacks, such as exhaustion of substrates and accumulation of fermentation products including protons, i.e. lowering of $\mathrm{pH}$. If data is used from a relatively short-term culture, such as in the present experiments, the bias due to these factors may be acceptable. However, a short-term experiment is not suitable for monitoring the time-course of the effect, or for testing the reversibility of the effect and the effect of cumulative dose. Thus, a continuous-culture technique was adopted for these purposes.

A one-step continuous culture without $\mathrm{pH}$-stat was used in the time-course study. This procedure should involve the simplest type of continuous-culture technique. The singlestep culture was preferred because our interest was mainly in the fermentation in the proximal part of the large bowel, the main site of SCFA production and absorption.

Filtered and autoclaved pig ileal contents diluted with the same volume of bicarbonate buffer were 'fed' at a dilution rate of $0.5 / \mathrm{d}$. This procedure was designed to simulate the influx of ileal contents and to facilitate the outflow of culture contents, thus simulating their efflux. Infusion of bicarbonate buffer effectively stabilized the $\mathrm{pH}$, even in the absence of an active $\mathrm{pH}$-stat.

\section{Variables measured}

The concentrations of organic acids were measured by HPLC, those of $\mathrm{NH}_{4}$ by a photometric method and, in some experiments, those of DNA by optical absorption (Sakata et al. 1999).

\section{Effects of commercial probiotic preparations on short-chain fatty acid production in batch cultures: a dose-response study}

Four commercially-available probiotic preparations were tested: Bibalance (Shiseido Pharmaceutical Co. Ltd, Tokyo, Japan) containing Bifidobacterium longum and Bifidobacterium infantis; Neoracton (Asahi Beer Pharmaceuticals Co. Ltd, Tokyo, Japan) containing Enterococcus faecalis and Bifidobacterium sp.; Yakult Seichoyaku BL (Yakult 
Honsha Co. Ltd, Tokyo, Japan) containing Lactobacillus casei and Bifidobacterium breve; Yakult Seichoyaku (Yakult Honsha Co. Ltd) containing L. casei and Enterococcus faecalis (Sakata et al. 1999). For this purpose $1 \mathrm{ml}$ batch cultures were used.

Probiotic preparations were digested with $\mathrm{HCl}$ and pancreatin to simulate passage through the stomach and small intestine, and to remove additives, such as digestive enzymes, starch or lactose, that might be included in the preparations.

The digested preparations were added to the inoculum to make the final dose in the culture one, two or ten times the recommended daily dose per litre and cultured at $37^{\circ} \mathrm{C}$. The inoculum was also cultured without the digested preparation (blank cultures). Such cultures were repeated three times using different sets of donor pigs.

The incubation was stopped after 0,8 or $24 \mathrm{~h}$ and centrifuged at $12000 \mathrm{~g}$ for $5 \mathrm{~min}$ at $4^{\circ} \mathrm{C}$. The supernatant fraction was analysed for organic acids and $\mathrm{NH}_{4}$.

Net production rates for each metabolite between 0 and $8 \mathrm{~h}$ and between 8 and $24 \mathrm{~h}$ were calculated by subtracting the concentration of the metabolite from that for the preceding sampling time in each case.

\section{Production rates of organic acids and ammonia}

The highest dose of probiotic preparations generally increased the production rate of SCFA, lactate and succinate and decreased that of isovaleric acid and $\mathrm{NH}_{4}$ between 8 and $24 \mathrm{~h}$ of culture (Table 1). The difference among different preparations was not significant.

\section{Correlation among dose and net production rates of metabolites}

Pearson correlation matrices were calculated for the dose of the preparation and the net production rates of metabolites between 8 and $24 \mathrm{~h}$ of incubation for each preparation (Table 2). The results for the Yakult Seichoyaku BL and Yakult Seichoyaku preparations were unequivocal. There were positive correlations among dose and production rates of SCFA, lactate and succinate and negative correlations between dose and net production rates of $\mathrm{NH}_{4}$ and isovaleric acid for these preparations. Net production rates of SCFA, lactate and succinate were negatively correlated with those of $\mathrm{NH}_{4}$ and isovaleric acid.

\section{Dose-dependent effects of probiotics on the net breakdown of carbohydrates and protein}

The correlations indicate that probiotic preparations, especially Yakult Seichoyaku BL and Yakult Seichoyaku, dosedependently increased SCFA production, by stimulating the breakdown of residual carbohydrates in caecal contents, and decreased net breakdown of protein. The latter might have been the result of increased utilization of $\mathrm{NH}_{4}$ and isovaleric acid for bacterial cell protein synthesis facilitated by an increase in energy supply from carbohydrate breakdown.

It is of note that the addition of probiotic bacteria did not change the basic profile of organic acid production. The probiotic preparations used in the present study contained different bacterial species with different fermentation profiles. However, their effects on organic acid production were very similar. This finding indirectly indicates active inter-acid conversion in the caecal bacterial ecosystem. Thus, it may be oversimplification to suggest, for example, that 'lactic acid production can be stimulated by adding lactic acid-producing bacteria'. The overall reaction in this ecosystem is not that straightforward.

Considering that donor pigs were fasted at least overnight, easily-fermentable carbohydrates in the original caecal contents should have been depleted. This outcome was confirmed by the very slow production of SCFA in blank cultures (Table 1). Thus, it is likely that probiotic

Table 1. Least-square means of net production rate ( $\mathrm{mmol} / / \mathrm{l}$ per $\mathrm{h}$ ) of bacterial metabolites in batch cultures using pig caecal bacteria with or without probiotic preparations between 8 and $24 \mathrm{~h}$ of incubation* (from Sakata et al. 1999) (Values are least-square means for three determinations)

\begin{tabular}{|c|c|c|c|c|c|c|c|c|c|}
\hline Probiotic preparation & $\begin{array}{l}\text { Dose } \\
\text { (pouches/l) }\end{array}$ & $\begin{array}{l}\text { Acetic } \\
\text { acid }\end{array}$ & $\begin{array}{l}\text { Propionic } \\
\text { acid }\end{array}$ & $\begin{array}{l}\text { n-Butyric } \\
\text { acid }\end{array}$ & $\begin{array}{l}\text { n-Valeric } \\
\text { acid }\end{array}$ & $\begin{array}{l}\text { Succinic } \\
\text { acid }\end{array}$ & $\begin{array}{l}\text { Lactic } \\
\text { acid }\end{array}$ & $\begin{array}{l}\text { Isovaleric } \\
\text { acid }\end{array}$ & $\mathrm{NH}_{4}$ \\
\hline \multirow[t]{2}{*}{ Bibalance } & 6 tablets/l & $2 \cdot 03^{a}$ & $0 \cdot 89^{a}$ & $0.31^{\mathrm{ab}}$ & 0.03 & $-0.03^{a}$ & $-0.08^{a}$ & $0 \cdot 15^{b}$ & $1 \cdot 28^{b}$ \\
\hline & 60 tablets/l & $5 \cdot 69^{b}$ & $2 \cdot 06^{\mathrm{bc}}$ & $0.87^{\mathrm{bc}}$ & 0.03 & $-0.05^{a}$ & $-0.08^{a}$ & $0.04^{a b}$ & $0 \cdot 25^{a}$ \\
\hline \multirow[t]{3}{*}{ Neoracton } & 3 & $1 \cdot 83^{a}$ & $0.94^{\mathrm{ab}}$ & $0 \cdot 22^{\mathrm{ab}}$ & 0.01 & $-0.03^{a}$ & $-0.08^{a}$ & $0 \cdot 13^{b}$ & $0.98^{b}$ \\
\hline & 6 & $1 \cdot 60^{a}$ & $0 \cdot 74^{a}$ & $0 \cdot 19^{a b}$ & 0.02 & $-0 \cdot 18^{a}$ & $-0.08^{a}$ & $0 \cdot 14^{b}$ & $1 \cdot 25^{b}$ \\
\hline & 30 & $3 \cdot 62^{a b}$ & $1 \cdot 79^{b c}$ & $0 \cdot 44^{b}$ & 0.03 & $-0.04^{a}$ & $-0.09^{a}$ & $0 \cdot 14^{b}$ & $1 \cdot 51^{b}$ \\
\hline \multirow[t]{3}{*}{ Yakult Seichoyaku BL } & 3 & $2 \cdot 27^{a}$ & $1 \cdot 07^{\mathrm{ab}}$ & $0 \cdot 28^{a b}$ & 0.02 & $-0.02^{a}$ & $-0.08^{a}$ & $0 \cdot 10^{b}$ & $1 \cdot 19^{b}$ \\
\hline & 6 & $3 \cdot 26^{a b}$ & $1 \cdot 40^{\mathrm{ab}}$ & $0 \cdot 44^{b}$ & 0.05 & $-0.05^{a}$ & $-0.09^{a}$ & $0 \cdot 10^{b}$ & $1 \cdot 10^{b}$ \\
\hline & 30 & $7 \cdot 28^{b}$ & $2 \cdot 49^{c}$ & $1 \cdot 32^{c}$ & 0.11 & $0 \cdot 35^{b}$ & $0.52^{c}$ & $0 \cdot 03^{a}$ & $-0 \cdot 14^{a}$ \\
\hline \multirow[t]{3}{*}{ Yakult Seichoyaku } & 3 & $2 \cdot 62^{a}$ & $1 \cdot 22^{\mathrm{ab}}$ & $0 \cdot 41^{a b}$ & -0.01 & $-0.05^{a}$ & $-0.09^{a}$ & $0 \cdot 14^{b}$ & $1 \cdot 19^{b}$ \\
\hline & 6 & $4 \cdot 02^{a b}$ & $1 \cdot 72^{\mathrm{bc}}$ & $0.59^{b}$ & 0.04 & $-0.05^{a}$ & $-0.09^{a}$ & $0 \cdot 12^{b}$ & $1 \cdot 06^{b}$ \\
\hline & 30 & $6 \cdot 93^{b}$ & $2 \cdot 29^{b c}$ & $1 \cdot 05^{c}$ & 0.04 & $0.52^{b}$ & $2 \cdot 75^{b}$ & $0 \cdot 01^{a}$ & $-0 \cdot 18^{a}$ \\
\hline Blank & None & $2 \cdot 31^{a}$ & $1 \cdot 00^{\mathrm{ab}}$ & $0.09^{a}$ & 0.05 & $0.00^{a}$ & $-0.06^{a}$ & $0 \cdot 12^{b}$ & $1 \cdot 05^{b}$ \\
\hline$P($ ANOVA $)$ & & 0.001 & $0 \cdot 001$ & 0.001 & $0 \cdot 138$ & 0.001 & 0.001 & 0.001 & 0.001 \\
\hline
\end{tabular}

EMS, error mean square of preliminary ANOVA (error df 38 )

a,b,c Mean values within a column with unlike superscript letters were significantly different (Tukey's multiple comparison using ANOVA EMS; $P<0 \cdot 05$ ).

${ }^{\star}$ For details of probiotic preparations and procedures, see p. 74. 
Table 2. Pearson correlation matrices for dose of probiotic preparation and net production rates of bacterial metabolites in batch cultures using pig caecal bacteria with or without probiotic preparations between 8 and $24 \mathrm{~h}$ of incubation* (from Sakata et al. 1999)

\begin{tabular}{|c|c|c|c|c|c|c|c|c|c|}
\hline Probiotic preparation & & Dose & Acetate & Propionate & n-Butyrate & $\mathrm{n}$-Valerate & Succinate & Lactate & Isovalerate \\
\hline \multirow[t]{6}{*}{ Yakult Seichoyaku BL } & Acetate & 0.970 & & & & & & & \\
\hline & Propionate & 0.960 & 0.992 & & & & & & \\
\hline & n-Valerate & 0.931 & 0.888 & $0 \cdot 872$ & 0.923 & & & & \\
\hline & Succinate & 0.905 & 0.919 & $0 \cdot 872$ & 0.914 & $0 \cdot 763$ & & & \\
\hline & Lactate & 0.874 & 0.905 & $0 \cdot 852$ & 0.906 & $0 \cdot 752$ & 0.992 & & \\
\hline & $\mathrm{NH}_{4}$ & -0.953 & -0.944 & -0.944 & -0.913 & -0.833 & -0.889 & $-0 \cdot 850$ & \\
\hline \multirow[t]{6}{*}{ Yakult Seichoyaku } & Acetate & 0.926 & & & & & & & \\
\hline & Propionate & $0 \cdot 788$ & 0.956 & & & & & & \\
\hline & $\begin{array}{l}\text { n-Butyrate } \\
\text { n-Valerate }\end{array}$ & 0.905 & 0.972 & 0.944 & & & & & \\
\hline & Succinate & 0.972 & 0.935 & $0 \cdot 827$ & 0.932 & & & & \\
\hline & Lactate & 0.977 & 0.929 & $0 \cdot 798$ & 0.899 & & 0.979 & & \\
\hline & Isovalerate & -0.974 & -0.904 & $-0 \cdot 757$ & $-0 \cdot 843$ & & -0.940 & -0.940 & \\
\hline
\end{tabular}

All correlation coefficients shown were significant $(P<0.05)$.

${ }^{*}$ For details of probiotic preparations and procedures, see p. 74 .

bacteria stimulate the utilization of carbohydrates that are relatively resistant to the enzymes of indigenous bacteria.

\section{Effects of probiotic preparations in the presence of glucose and polypeptone}

The earlier results demonstrate that probiotic preparations actually increase the production of SCFA, at least in vitro. However, this outcome is not sufficient to explain their antidiarrhoeic effect in vivo because undigested carbohydrates and proteins may enter the large bowel under certain diarrhoeic circumstances. Thus, the possibility that probiotic preparations increase SCFA production in the presence of easily-fermentable carbohydrate (glucose) and proteinaceous material (polypeptone) was investigated using a batch-culture technique (Fujieda \& Sakata, 2002).

A two-way factorial experiment was conducted for this purpose. One factor was the addition of artificially-digested probiotic preparations. The preparations used were Yakult Seichoyaku and Yakult Seichoyaku BL (both used in the earlier study) and Miyarisan containing Clostridium butyricum (Miyarisan Co. Ltd, Tokyo, Japan). Another factor was the addition of glucose or polypeptone.

Results were remarkable. Glucose abolished the effect of probiotic preparations (Fig. 1). The effect of glucose was far larger and appeared earlier than that of probiotic preparations. On the other hand, probiotic preparations increased SCFA production and reduced production of $\mathrm{NH}_{4}$ and branched-chain fatty acids when added to blank cultures and cultures with added polypeptone.

Thus, probiotics were not able to increase SCFA production in the presence of readily-fermentable carbohydrate (glucose). Lactobacilli, present in some of the probiotic preparations used in the present study, are able to utilize glucose as their principal substrate (Bongaerts, 2001). Nevertheless, glucose did not enhance the effect of Lactobacilli-containing probiotic preparations.
On the other hand, proteins did not interfere with the stimulatory effect of probiotics on SCFA production. Thus, it is likely that probiotics stimulate SCFA production more markedly when host animals or human subjects have no oral supply of foods or are supported with totally-digestible nutrients.

However, it can be argued that glucose is not a saccharide usually found in the lumen of the large bowel. Thus, another batch-culture study was conducted.

\section{Effects of probiotic bacteria in the presence of starch, lactose and gastric mucin}

A two-way factorial experiment was conducted (T Michibata and T Sakata, unpublished results) in which one factor was the addition of probiotic bacteria and another factor was the addition of carbohydrates that usually enter the large intestine of man. The intention was also to test the effect of individual probiotic species at defined doses.

\section{Probiotic bacteria}

Bacteria of different fermentation profiles were tested, i.e. C. butyricum, S. thermophilis or L. bulgaricus. They were grown in appropriate media and administered to the culture after measuring their density in the growth media with a haemocytometre (Nikon, Tokyo, Japan).

\section{Carbohydrates}

The sources used were starch, lactose and pig gastric mucin. The first two sources represented dietary fermentable carbohydrates that often enter the large intestine of man (at least in lactose-intolerant individuals) and pigs. Gastric mucin represented carbohydrate of endogenous origin. Gastric mucin was preferred to caecal or colonic mucin because mucin secreted from the upper digestive organs 


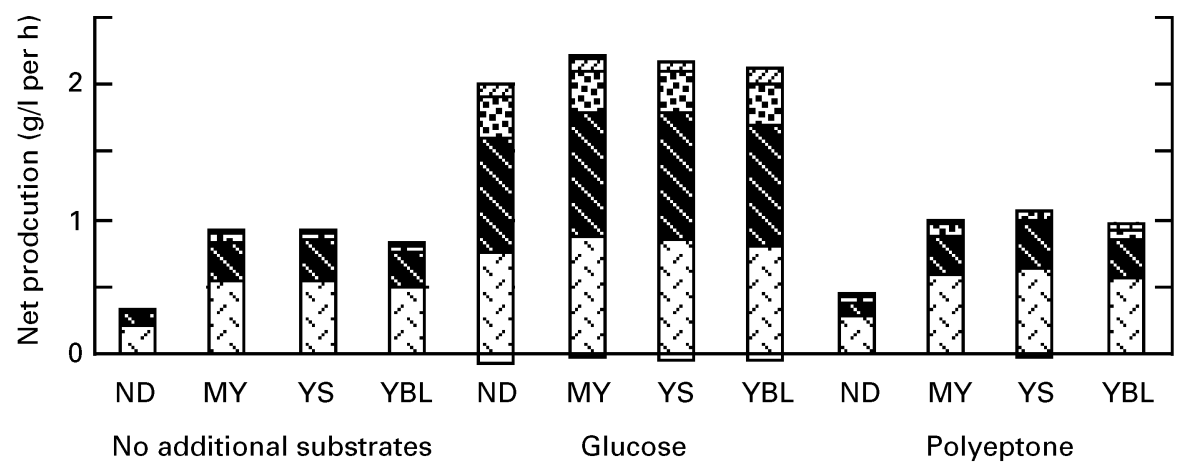

\begin{tabular}{lcccccc}
\hline Factor & Acetic & Propionic & n-Butyric & n-Valeric & Succinic & Lactic \\
\hline SEM $(n 4)$ & 0.7 & 0.6 & 0.3 & 0.3 & 0.0 & 0.4 \\
Preparation & 0.001 & 0.001 & $\mathrm{NS}$ & $\mathrm{NS}$ & $\mathrm{NS}$ & $\mathrm{NS}$ \\
& $\mathrm{YBL}=\mathrm{YS}=\mathrm{MY}>\mathrm{ND}$ & $\mathrm{YBL}=\mathrm{YS}=\mathrm{MY}>\mathrm{ND}$ & & & \\
Substrate & 0.001 & 0.001 & 0.001 & 0.001 & $\mathrm{NS}$ & $\mathrm{NS}$ \\
& $\mathrm{G}>\mathrm{P}>\mathrm{N}$ & $\mathrm{G}>\mathrm{P}=\mathrm{N}$ & $\mathrm{G}>\mathrm{P}=\mathrm{N}$ & $\mathrm{G}>\mathrm{P}=\mathrm{N}$ & & \\
Interaction & $\mathrm{NS}$ & $\mathrm{NS}$ & $\mathrm{NS}$ & $\mathrm{NS}$ & $\mathrm{NS}$ & $\mathrm{NS}$ \\
\hline
\end{tabular}

Fig. 1. Effect of probiotic preparations (five times the daily dose per I) and the addition of glucose or polypeptone $(5 \mathrm{~g} / \mathrm{l})$ on production rates of organic acids between 1 and $6 \mathrm{~h}$ of batch culture of pig caecal contents. ND, no additional preparation; MY, Miyarisan preparation; YS, Yakult Seichoyaku preparation;

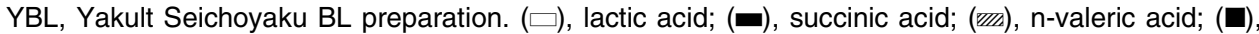
n-butyric acid; ( see pp. 74 and 76 . The significance of the effects of the probiotic preparations and substrate addition and their interaction (by ANOVA) are also shown. N, no additional substrates; $\mathrm{P}$, polypeptone added; $\mathrm{G}$, glucose added.

constitutes the major part of the mucin in the bulk-phase contents (Meslin et al. 1993), from which the inoculum was taken.

\section{Batch-culture system}

A $5 \mathrm{ml}$ batch culture was used, with half-diluted pig caecal contents as the inoculum. One of the bacterial species (or none) and one of the carbohydrates (or none), both at two different levels, were added and the net production rates of organic acids and DNA measured. The DNA level was used to estimate the total size of the bacterial population in the culture.

\section{Effects of probiotic bacteria}

There was no significant interaction (Table 3); neither dietary nor endogenous carbohydrate modified the effect of probiotics on net organic acid production. In other words, probiotic bacteria did not enhance the breakdown of these carbohydrates. The effect of probiotic bacteria was already maximal at $10^{7} / 1$ (Table 3 ). Thus, the inability of probiotic bacteria to enhance the fermentation of additional carbohydrate was not due to an insufficient dose of probiotic bacteria.
No significant difference was detected among three probiotic species in terms of organic acid production (Table 3). This finding confirms the results of earlier experiments (Sakata et al. 1999; Fujieda \& Sakata, 2002). A butyrate producer such as $C$. butyricum does not shift the production of SCFA towards a butyrate-rich profile.

Thus, probiotic species are able to increase SCFA production in the presence of such carbohydrates. This finding apparently conflicts with the effect of glucose described earlier. However, glucose is a monosaccharide rapidly used by a wide range of bacterial species. Thus, the addition of glucose should have accelerated the growth of different species at a time, and the production of organic acids at the same time, leading to the very rapid production of these acids by the dominant population in the ecosystem and masking the effect of probiotic species. On the other hand, not all bacteria can degrade starch, lactose or mucin. Accordingly, the production of organic acids is not as rapid as in the case of glucose addition, making it possible for probiotic species to provide indigenous species with energy or C sources from carbohydrates left in the caecal contents.

Interestingly, there was no significant decrease in net disappearance of DNA. Thus, the increase in energy supply to the ecosystem by probiotic species, even at the maximal 
level, was not sufficient to support the total population size of the bacterial ecosystem.

\section{Effects of carbohydrates}

Starch is a preferred energy substrate for $C$. butyricum, while lactose is readily utilized by the other two probiotic species (Bongaerts, 2001). Accordingly, starch and lactose might have functioned as prebiotics. However, these carbohydrates did not modify the effect of probiotics (Table 3 ). This finding also suggests that probiotic species enhance the SCFA production, not from the added carbohydrates, but from the carbohydrates already present in the caecal contents. This explanation is supported by the indifferent yield (organic acids produced:added carbohydrate) of approximately $0 \cdot 6$, independent of the addition of probiotic species (data not shown). Since the addition of gastric mucin did not increase the effect of probiotic species (Table 3), gastric mucin may not be the carbohydrate source that is preferentially degraded by probiotic species.

Based on this finding and those of the earlier studies, it could be suggested that a critical review of the concept of 'prebiotics' is necessary, at least with regard to SCFA production. Prebiotic saccharides, such as some indigestible oligosaccharides, may function just by providing energy and $\mathrm{C}$ to the entire bacterial ecosystem to increase SCFA production, and their effects may not necessarily require the growth promotion of specific probiotic species. Additional carbohydrates, especially starch and lactose, dose-depend- ently reduced net degradation of DNA to turn it into net production at a higher dose level $(10 \mathrm{~g} / \mathrm{l}$; data not shown). This effect was not maximal at $10 \mathrm{~g} / \mathrm{l}$. The maximum should occur at approximately 15-20 g/l (Kikuchi \& Sakata, 1992). This finding suggests that the supply of fermentable carbohydrate(s) to the large bowel is an effective way of increasing the size of the bacterial population in the ecosystem and thereby increasing the capacity for SCFA production from carbohydrates.

Regression analysis of the data indicated that the equilibrium of the bacterial population size, i.e. zero net degradation and production of DNA, was achieved at a dose of approximately $8 \mathrm{~g} / \mathrm{l}$ in the present batch-culture system. Considering that probiotic species increased SCFA production, especially acetic acid, independent of carbohydrate addition, probiotic species can stimulate SCFA production during both the expansion and shrinkage of the total bacterial population.

\section{Relative contribution of probiotic bacteria and additional carbohydrates}

Statistical analysis (sum of squares, two-way ANOVA) indicated that probiotic bacteria and additional carbohydrates contributed to the increase in acetic acid production to a similar extent (Table 3). However, the contribution of the additional carbohydrates to the production of SCFA other than acetic acid was much greater than that of the probiotic bacteria.

Table 3. Mean net production rates ( $\mathrm{mmol} / \mathrm{l}$ per $\mathrm{h}$ ) of various organic acids during the first $12 \mathrm{~h}$ in batch cultures of pig caecal contents with added probiotic bacteria and carbohydrates (T Michibata and T Sakata, unpublished results) (Values are means for three determinations)

\begin{tabular}{|c|c|c|c|c|c|c|c|}
\hline & & Acetic acid & Propionic acid & n-Butyric acid & n-Valeric acid & Lactic acid & Succinic acid \\
\hline \multicolumn{8}{|l|}{ Probiotic bacteria } \\
\hline \multirow[t]{2}{*}{ Lactobacillus bulgaricus: } & $10^{7} / /$ & $420^{c}$ & $172^{\mathrm{b}}$ & $87^{\mathrm{ab}}$ & $44^{\mathrm{ab}}$ & $-11 \cdot 0$ & $-0 \cdot 6$ \\
\hline & $10^{9} / 1$ & $442^{c}$ & $182^{\mathrm{b}}$ & $97^{b}$ & $47^{b}$ & $-7 \cdot 7$ & -0.9 \\
\hline \multicolumn{2}{|c|}{ Streptococcus thermophilis: $10^{7} / \mid$} & $391^{b c}$ & $150^{a b}$ & $69^{a}$ & $40^{\mathrm{ab}}$ & $-4 \cdot 2$ & $-1 \cdot 0$ \\
\hline & $10^{9} / 1$ & $390^{\mathrm{bc}}$ & $152^{\mathrm{ab}}$ & $78^{\mathrm{ab}}$ & $45^{\mathrm{b}}$ & $-6 \cdot 3$ & $-1 \cdot 3$ \\
\hline \multirow[t]{2}{*}{ Clostridium butyricum: } & $10^{7} / /$ & $294^{a b}$ & $154^{\mathrm{ab}}$ & $75^{\mathrm{ab}}$ & $35^{\mathrm{ab}}$ & $-4 \cdot 8$ & -0.7 \\
\hline & $109 / 1$ & $340^{\mathrm{bc}}$ & $157^{a b}$ & $77^{a b}$ & $38^{a b}$ & $-4 \cdot 7$ & $-1 \cdot 0$ \\
\hline No probiotics & & $217^{a}$ & $136^{a}$ & $64^{a}$ & $33^{a}$ & $-2 \cdot 9$ & -0.6 \\
\hline \multicolumn{8}{|l|}{ Substrate } \\
\hline \multirow[t]{2}{*}{ Lactose: } & $5 \mathrm{~g} / \mathrm{l}$ & $338^{b}$ & $149 \mathrm{bc}$ & $74^{\mathrm{bc}}$ & $26^{a}$ & $-6 \cdot 5$ & $-1 \cdot 0^{a b}$ \\
\hline & $10 \mathrm{~g} / \mathrm{l}$ & $387^{b}$ & $242^{d}$ & $126^{e}$ & $50^{\mathrm{b}}$ & $-7 \cdot 8$ & $-1 \cdot 2^{b}$ \\
\hline \multirow[t]{2}{*}{ Starch: } & $5 \mathrm{~g} / \mathrm{l}$ & $304^{a b}$ & $142^{b c}$ & $74^{\mathrm{bc}}$ & $27^{a}$ & $-9 \cdot 1$ & $-0.7^{a b}$ \\
\hline & $10 \mathrm{~g} / \mathrm{l}$ & $355^{b}$ & $214^{d}$ & 109 de & $45^{b}$ & $-9 \cdot 1$ & $-1 \cdot 5^{b}$ \\
\hline \multirow[t]{2}{*}{ Mucin: } & $5 \mathrm{~g} / \mathrm{l}$ & $380^{\mathrm{b}}$ & $123^{b}$ & $54^{b}$ & $45^{b}$ & $-7 \cdot 6$ & $-0.7^{a b}$ \\
\hline & $10 \mathrm{~g} / \mathrm{l}$ & $512^{\mathrm{c}}$ & $173^{c}$ & $87^{\mathrm{cd}}$ & $72^{c}$ & $-1 \cdot 0$ & $-0.8^{a b}$ \\
\hline \multicolumn{2}{|l|}{ No probiotics, no substrates } & 160 & 45 & 10 & 3 & -0.7 & 0.3 \\
\hline \multicolumn{2}{|l|}{ Pooled SD* } & 113 & 36 & 26 & 13 & $11 \cdot 5$ & $1 \cdot 1$ \\
\hline \multicolumn{8}{|l|}{ Sum of squares } \\
\hline \multicolumn{2}{|l|}{ Probiotics } & 756820 & 28410 & 14902 & 3354 & 912 & 8 \\
\hline \multicolumn{2}{|l|}{ Substrate } & 984328 & 441654 & 140834 & 43139 & 1590 & 21 \\
\hline \multicolumn{8}{|l|}{ Error: $P=$} \\
\hline \multicolumn{2}{|l|}{ Probiotics } & 0.001 & 0.003 & 0.003 & 0.006 & 0.338 & 0.356 \\
\hline \multicolumn{2}{|l|}{ Substrate } & 0.001 & 0.001 & 0.001 & 0.001 & 0.072 & 0.015 \\
\hline \multicolumn{2}{|l|}{ Interaction } & 0.999 & 0.993 & 0.978 & 0.999 & 0.450 & 0.999 \\
\hline
\end{tabular}

a,b,c Mean values within a column with unlike superscript letters were significantly different (Tukey's multiple comparison; $P<0.05$ ).

* Square root of error mean square of preliminary analysis of covariance. 


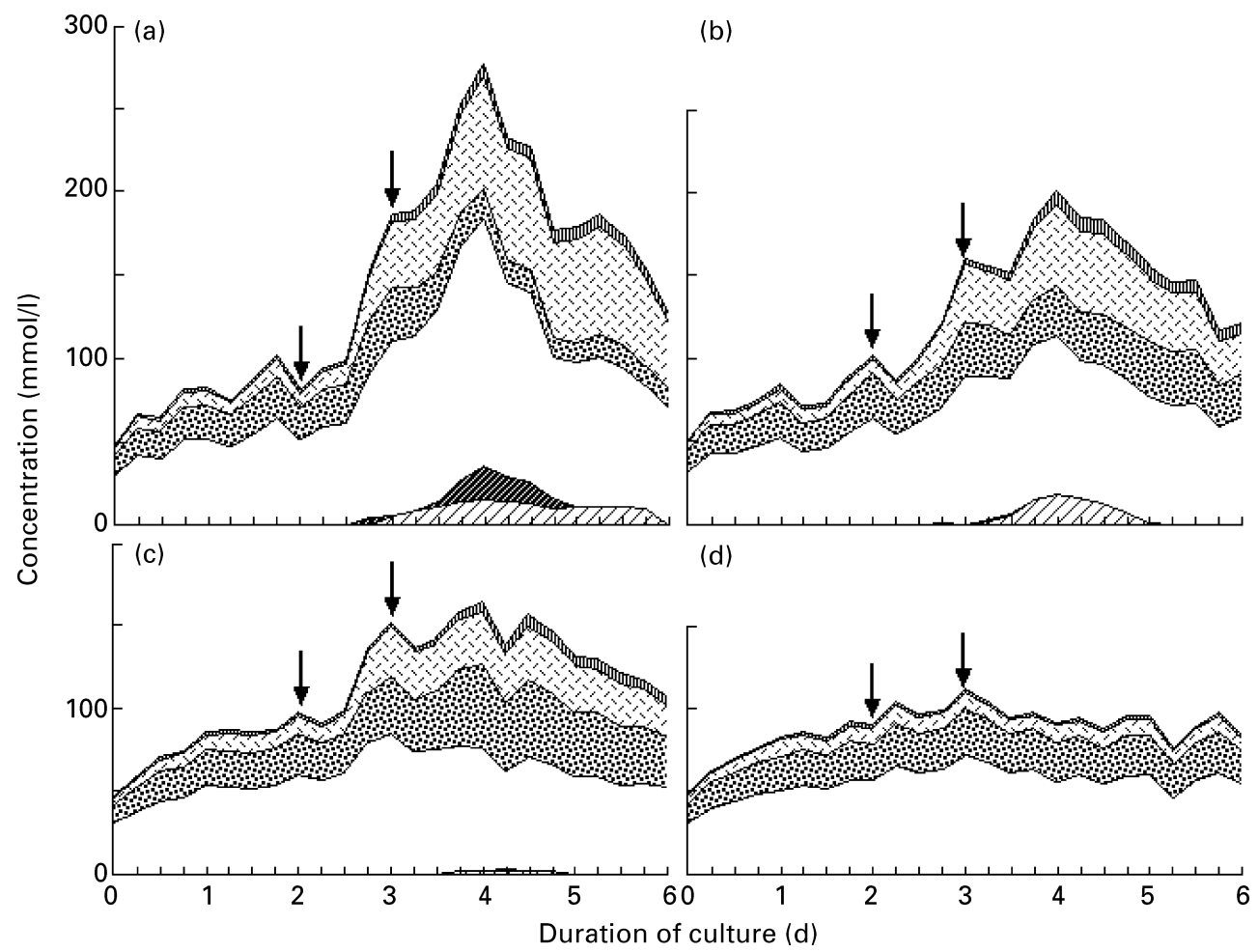

Fig. 2. Effect of probiotic preparations given at ten times the daily dose at 48 and $72 \mathrm{~h}(\downarrow)$ during the continuous culture of pig caecal contents ( $n 3$ ). (a), Yakult Seichoyaku; (b), Yakult Seichoyaku BL; (c), Miyarisan; (d), control.

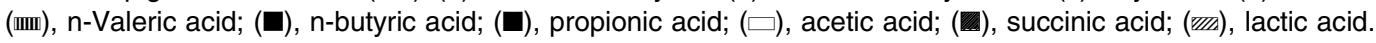
For details of probiotic preparations and procedures, see pp. 74 and 76. (From M Takahashi and T Sakata, unpublished results).

\section{Effects of probiotic preparations on organic acid production in continuous culture}

The time-course of the effects of probiotic preparations on organic acid production was studied using a single-step continuous-culture system without $\mathrm{pH}$-stat (M Takahashi and T Sakata, unpublished results). One of the three probiotic preparations (Yakult Seichoyaku, Yakult Seichoyaku BL and Miyarisan) used in previous studies was added at five times the daily dose per 1 at 48 and $72 \mathrm{~h}$ of culture and the organic acid concentrations of the culture monitored.

\section{Effects on organic acid production}

The culture had stabilized after $48 \mathrm{~h}$ and produced the expected levels of SCFA (Fig. 2). All probiotic preparations increased the production of SCFA during the $6 \mathrm{~h}$ after administration. The effect of probiotic preparations was cumulative, i.e. the second administration further increased the level of SCFA production. The effect of probiotic preparations disappeared within a few days.

\section{Conclusion}

These studies indicate that probiotic bacteria actually increase the production rates of SCFA, and sometimes those of lactic and succinic acids. This effect is mainly due to the increase in the breakdown of carbohydrates that are resistant to indigenous bacteria. The effect of probiotic bacteria is dose-dependent and is maximal at approximately $10^{7} / 1$. Their effect is apparent after a few hours and persists for a few days. Probiotic bacteria are able to exert their effect in the presence of various carbohydrates or protein, i.e. under the condition of simulated diarrhoea. However, the increase in SCFA production associated with probiotic bacteria is not as high as that associated with added carbohydrates.

The mechanism by which probiotic bacteria exert this effect is still unknown. They may have enzymes that are able to degrade carbohydrates that are resistant to indigenous gut bacteria. Alternatively, probiotic bacteria may secrete growth factors and thereby stimulate the proliferation of a certain group of indigenous bacteria, as suggested by Macfarlane \& Macfarlane (2003).

\section{Acknowledgements}

We are grateful for help and encouragement from the meat inspection officers at Senpoku Meat Inspection Centre (Yoneyamamachi, Miyagi, Japan). A part of this study was supported by a research grant from the Ito Memorial Foundation.

\section{References}

Barry J, Hoebler C, Macfarlane G, Macfarlane S, Mathers J, Reed K, Mortensen P, Nordgaard I, Rowland I \& Rumney C (1995) 
Estimation of the fermentability of dietary fibre in vitro: a European interlaboratory study. British Journal of Nutrition 74, 303-322.

Bengmark S \& Jeppsson B (1995) Gastrointestinal surface protection and mucosa reconditioning. Journal of Parenteral and Enteral Nutrition 19, 410-415.

Bongaerts GPA (2001) The beneficial, antimicrobial effect of probiotics. Medical Hypotheses 56, 174-177.

Cherbut C (2003) Motor effects of short-chain fatty acids and lactate in the gastrointestinal tract. Proceedings of the Nutrition Society 62, 95-99.

Fujieda M \& Sakata T (2002) Glucose but not polypeptone reduces the effect of probiotic preparations to stimulate carbohydrate breakdown and reduce net ammonia production by pig cecal bacteria in vitro. Journal of Medicinal Food 4, 231-240.

Fuller R (1991) Probiotics in human medicine. Gut 32, 439-442.

Gibson R \& Williams C (1999) Gut fermentation and health advantages: myth or reality? British Journal of Nutrition 81, 83-84.

Inagaki A \& Sakata T (2001) Fermentation of oligosaccharides and influences of fermentation products. In Advanced Dietary Fibre Technology, pp. 197-205 [BV McCleary and L Prosky, editors]. Oxford: Blackwell Science Ltd.

Ito I, Hayashi T, Iguchi A, Endo H, Nakao M, Kato S, Nabeshima T \& Ogura Y (1997) Effects of administration of Clostridium butyricum to patients receiving long-term tube feeding. Japanese Journal of Geriatrics 34, 298-304.

Kikuchi H \& Sakata T (1992) Qualitative and quantitative estimation of soluble indigestible polysaccharides as substrates for hindgut fermentation by mini-scale batch culture. Journal of Nutritional Sciences and Vitaminology 38, 287-296.

Kiriyama H, Hariu Y \& Sakata T (1992) Comparison of in vitro productivities of short-chain fatty acids and gases from aldoses and the corresponding alcohols by pig cecal bacteria. Journal of Nutritional Biochemistry 3, 447-451.

Macfarlane G \& Gibson G (1995) Microbiological aspects of shortchain fatty acids in the large bowel. In Physiological and Clinical Aspects of Short-chain Fatty Acids, pp. 87-105 [J Cummings, J Rombeau and $\mathrm{T}$ Sakata, editors]. Cambridge: Cambridge University Press.
Macfarlane S \& Macfarlane GT (2003) Regulation of short-chain fatty acid production. Proceedings of the Nutrition Society 62, $67-72$.

Meslin J, Andrieux C, Sakata T, Beaumatin P, Bensaada M, Popot F, Szylit O \& Durand M (1993) Effects of galactooligosaccharide and bacterial status on mucin distribution in mucosa and on large intestine fermentation in rats. British Journal of Nutrition 69, 903-912.

Okamoto T, Sasaki M, Araki Y, Fukuda M, Kimura T, Myojo S, Tsujikawa T, Fujiyama Y, Bamba T \& Kusunoki M (1996) Therapeutic efficiency of oral-administration of Clostridium butyricum. Digestion and Absorption 19, 65-68.

Pouteau E, Nguyen P, Ballèvre O \& Krempf (2003) Production rates and metabolism of short-chain fatty acids in the colon and whole body using stable isotopes. Proceedings of the Nutrition Society 62, 87-93.

Roediger R (1995) The place of short-chain fatty acids in colonocyte metabolism in health and ulcerative colitis: the impaired colonocyte barrier. In Physiological and Clinical Aspects of Short-chain Fatty Acids, pp. 337-351 [J Cummings, $\mathrm{J}$ Rombeau and $\mathrm{T}$ Sakata, editors]. Cambridge: Cambridge University Press.

Sakata T, Kojima T, Fujieda M, Miyakozawa M, Takahashi M \& Ushida K (1999) Probiotic preparations dose-dependently increase net production rates of organic acids and decrease that of ammonia by pig cecal bacteria in batch culture. Digestive Diseases and Sciences 44, 1485-1493.

Siigur U, Tamm E, Torm S, Lutsar I, Salminen S \& Midtvedt T (1996) Effect of bacterial infection and administration of a probiotic on faecal short-chain fatty acids. Microbial Ecology in Health and Disease 9, 271-277.

von Engelhardt W (1995) Absorption of short-chain fatty acids from the large intestine. In Physiological and Clinical Aspects of Short-chain Fatty Acids, pp. 149-170 [J Cummings, J Rombeau and T Sakata, editors]. Cambridge: Cambridge University Press. von Engelhardt W, Bartels J, Kirschberger S, Meyer Zu Düttingdorf H \& Busche R (1998) Role of short-chain fatty acids in the hind gut. Veterinary Quarterly 20, S52-S59. 